\title{
Natural diet and feeding habits of the crabs Liocarcinus puber and L. holsatus (Decapoda, Brachyura, Portunidae)
}

\author{
Satish C. Choy \\ Marine Science Group, University College of Swansea, Singleton Park, Swansea SA2 8PP, Wales, United Kingdom
}

\begin{abstract}
The foregut volumes of Liocarcinus puber and $L$. holsatus were related to body size as $y=$ $0.0338 \mathrm{e}^{0.0564} \mathrm{x}$ and $\mathrm{y}=0.0313 \mathrm{e}^{0.0598} \mathrm{x}$ respectively, where $\mathrm{y}=$ foregut volume $(\mathrm{ml})$ and $\mathrm{x}=$ carapace width $(\mathrm{mm})$. The amount of food remaining in the foregut of these crabs decreased exponentially with time so that for both species the foregut was half empty about $5 \mathrm{~h}$ after feeding and almost empty about $20 \mathrm{~h}$ later $\left(\mathrm{T}=13.5 \pm 1.5^{\circ} \mathrm{C}\right)$. However, shell fragments and algae were still found after 36 and $72 \mathrm{~h}$, respectively. Crustaceans (mainly crabs and barnacles) were the most important food group of juvenile L. puber, and brown algae (Laminaria and Fucus spp.) and bivalve molluscs (esp. Mytilus edulis) were the next 2 important groups. Algae were found predominantly in crabs $>25 \mathrm{~mm} \mathrm{CW}$. The main food group of adult L. puber was brown algae (Laminaria and Fucus spp.), occurring in about $80 \%$ of the foreguts examined and constituting over $40 \%$ of the total volume of diet (the highest ever recorded for portunid crabs). The next 2 major groups in their diet were crustaceans (anomuran crabs) and molluscs (M. edulis). Results strongly suggest that $L$. puber feeds selectively on algae and can also digest them. Crustaceans (esp. juvenile Crangon spp.), molluscs (esp. Spisula elliptica) and fish (probably juvenile gobies and pleuronectids) were the dominant food groups of L. holsatus. For both species diet was largely dependent upon local availability although, in the case of $L$. puber feeding on algae, other factors such as palatability, calorific/nutritive value and/or moult stage of the crab may have been important. Algae were eaten mainly between late spring and early autumn by $L$. puber in the early intermoult (B) stage. Despite the preponderance of brown algae in the natural diet of $L$. puber, in the laboratory these crabs preferred animal material. Activity patterns suggest that L. puber feeds only when submerged by the tide especially at night while L. holsatus seems to do so mainly during incoming and outgoing tides irrespective of the time of day. Most empty foreguts were found during winter (particularly in gravid female and parasitised crabs) although in summer a high proportion of recently moulted crabs also had empty foreguts. Calcareous material was sometimes found in soft crabs. This and other related studies suggest that despite the diversity in their diet and feeding habits portunid crabs are opportunistic omnivores with a preference for animal food and with predatory tendencies.
\end{abstract}

\section{INTRODUCTION}

Most crabs are foraging omnivores although certain families show tendencies towards a more specialised diet (Warner 1977). Portunid crabs are reported as being mainly carnivorous, preying on slow-moving invertebrates such as molluscs and crustaceans. Typical studies are those on Callinectes spp. (Tagatz 1968, Paul 1981), Carcinus maenas (Ropes 1968, Abbas 1985), Ovalipes spp. (Caine 1974, Du Preez 1984), Portunus pelagicus (Williams 1982) and Scylla serrata (Hill 1976). The diets of tropical and sub-tropical portunid crabs are relatively uniform because of high diversity and regular availability of prey species. In contrast, the diets of temperate species change markedly as a result of lower diversity and seasonal changes in the availability of prey species.

Despite the presence of over a dozen species of portunid crabs in the eastern North Atlantic coasts (Christiansen 1969, Ingle 1983) the diet and feeding behaviour are known for only 2 species, namely Carcinus maenas (Crothers 1968, Abbas 1985) and MaCropipus (now designated as Liocarcinus) puber (González Gurriarán 1978, 1981). The main prey of a population of $L$. puber inhabiting mussel culture areas in Ria de Arousa, Spain were crustaceans, molluscs, 
echinoderms and algae (González Gurriarán 1978, 1981). Predation on bivalves and gastropods (Kitching et al. 1959, Ebling et al. 1964) and sea urchins (Muntz et al. 1965) has also been reported for this species from Lough Inne, Eire. Handling methods and handling times of $L$. puber feeding on mussels Mytilus edulis, winkles Littorina rudis and juvenile shore crabs $C$. maenas were described by ap Rheinallt \& Hughes (1985) who suggested that $L$. puber is better equipped (based on chelal morphology) for predating on softer, more mobile prey such as crustaceans.

This paper presents the results of a study on the natural diets and some of the feeding habits of Liocarcinus puber (L.) and L. holsatus (Fabricius). It forms part of a wider study on their population dynamics and ecology in South Wales where both species are locally abundant. L. puber is of economic interest along some stretches of the British Isles coastline (see MacMullen 1983).

\section{MATERIALS AND METHODS}

Field collection. Random subsamples were taken from routine monthly samples of Liocarcinus puber and L. holsatus between January 1984 and July 1985 for analysis of gut contents.

Linocarcinus puber was collected by hand intertidally at Langland Bay (Ordnance Survey map reference SS607871, Sheet 159) and Worm's Head Sound, Rhossili (SS399873) on the Gower Peninsula, South Wales. Routine collections were made by searching under boulders and rocks during low water of spring tides (between 1000 and $1600 \mathrm{~h}$ ). Some crabs were collected at other times. Sublittoral samples were obtained at irregular intervals by SCUBA or snorkelling.

Liocarcinus holsatus was collected using a $2 \mathrm{~m}$ beam trawl (19 $\mathrm{mm}$ mesh net and a $9.5 \mathrm{~mm}$ mesh cod-end) from Swansea Bay (SS6789) and occasionally from Oxwich Bay (SS5386) and Carmarthen Bay (SS3790) at depths between 3 and $20 \mathrm{~m}$ below chart datum. All trawls were of 20 to 30 min duration.

Whenever possible 30 adult and 30 juvenile crabs of each sex were analysed following the reasons given by Williams (1981). However, low catches sometimes precluded this and fewer crabs were examined. All crabs used for analysis of gut contents were killed within $3 \mathrm{~h}$ of capture. Some specimens were analysed immediately and others were preserved in 5 to $10 \%$ seawaterformalin solution for analysis later. For this purpose the carapace of each crab was pulled slightly away from the body to allow rapid penetration of the preservative. These crabs were analysed within 2 wk. Each crab was sexed, weighed and the carapace width measured.
Carapace width (CW) is defined as the distance between indentations of the 4 th and 5 th teeth on the anterolateral margins of the carapace. A record was also made of the approximate moult stage, using criteria of Williams (1982), the reproductive condition of the female, and the incidence of parasites.

Foregut volume and analysis of foregut contents. Stomach fullness was estimated using the method described by Hill (1976) who also related carapace width of the crab to the maximum foregut volume by regression. The foreguts of 32 freshly killed male Liocarcinus puber (15 to $72 \mathrm{~mm} \mathrm{CW}$ ) and of $48 \mathrm{~L}$. holsatus (18 to $35 \mathrm{~mm} \mathrm{CW}$ ) were analysed in this way.

The percentage fullness of other foreguts was derived by dividing the observed volume of the food contents by the maximum volume for a particular size of crab. The contents were then identified to the lowest possible taxon and their frequency of occurrence noted. The amount of each categorized food item in the foregut was estimated volumetrically (Hill 1976, Jewett \& Feder 1982) in terms of the relative volumes occupied and expressed as a percentage (total volume of contents taken as $100 \%$ ).

The Spearman rank correlation test (Snedecor \& Cochran 1980) was used to test the correlation between the frequency of occurrence and the percent volume of foregut contents. The Wilcoxon signed-ranks tests was used in determining feeding differences between areas, juveniles \& adults, sexes, gravid \& non-gravid females and, in the case of Liocarcinus holsatus, also between crabs infected by the rhizocephalan parasite Sacculina carcini Thompson and those that were not.

Rate of foregut clearance. In order to determine the times and patterns of feeding, the rate of foregut clearance of the crabs was estimated. Male specimens of Liocarcinus puber (20 to $70 \mathrm{~mm} \mathrm{CW}$ ) and L. holsatus (18 to $35 \mathrm{~mm}$ ) were kept individually in a clean polypropylene aquarium $(55 \times 35 \times 17 \mathrm{~cm})$ with recirculating sea water $\left(\mathrm{T}=13.5 \pm 1.5^{\circ} \mathrm{C}, \mathrm{S}=32 \pm 2\right.$ ppt., $\mathrm{pH}=7.2 \pm 0.2)$ and starved for $72 \mathrm{~h}$ to standardise the hunger level. A tile or stone shelter was put into each tank, under which the crab spent most of the light hours. After the starvation period, known wet (tissue paper dried) weights (5 to $10 \mathrm{~g}$ ) of mussel Mytilus edulis L. meat was placed in each tank. The crabs were observed every $10 \mathrm{~min}$ until they were thought to have completed feeding, after which all uneaten food was removed and its wet and dry weight (to constant weight at $80^{\circ} \mathrm{C}$ ) determined. Additional samples of mussel meat were weighed fresh and after drying to provide calibration between their length, wet and dry weights. Crabs (in batches of 3) were killed at various time intervals after feeding and the food remaining in the foregut was removed and its wet and dry weights determined. The clearance rates of shell fragments and 
algae in $L$. puber were estimated using live mussels and Laminaria digitata (Hudson), respectively.

Predation and prey selection. Various sizes (15 to $75 \mathrm{~mm} \mathrm{CW}$ ) of Liocarcinus puber were caught from Langland Bay and maintained individually in the polypropylene aquarium and various food items such as different size classes of mussels (separated and in clusters), crabs (Porcellana platycheles [Pennant]) and algae (Laminaria spp. and Fucus spp., with and without epiphytes) were presented to the crabs to study the predation patterns and to see if preference for any food items existed. For prey and size selection experiments L. puber was starved for $72 \mathrm{~h}$ prior to presentation of test food items. Each presentation was made at intervals of about $24 \mathrm{~h}$ to eliminate satiation effects. Daily intake rates were estimated over $15 \mathrm{~d}$ during which the crabs were supplied with known but abundant quantities of food every day.

The G-test for goodness-of-fit (Zar 1974) was used to examine the null hypothesis that the crabs had eaten an equal number from each size class of mussels or each type of food item (the latter presented on a similar weight basis).

\section{RESULTS}

\section{Foregut volume}

The foregut volumes of Liocarcinus puber and $L$. holsatus were found to be exponentially related to the carapace width by the regression equations:

L. puber: $\mathrm{y}=0.0338 \mathrm{e}^{0.0564} \mathrm{x}$;

$\mathrm{r}=0.94, \mathrm{n}=32, \mathrm{P}<0.001$;

L. holsatus: $\mathrm{y}=0.0313 \mathrm{e}^{0.0598} \mathrm{x}$;

$r=0.91, \mathrm{n}=48, \mathrm{P}<0.001$;

where $\mathrm{y}=$ foregut volume, $\mathrm{ml} ; \mathrm{x}=$ carapace width, $\mathrm{mm}$. According to these equations $L$. puber of carapace widths $10,20,40$ and $60 \mathrm{~mm}$ would have foregut volumes of $0.06,0.10,0.32$ and $1.0 \mathrm{ml}$, respectively while $L$. holsatus of the first 3 sizes would have foregut volumes of $0.04,0.10$ and $0.34 \mathrm{ml}$, respectively. L. holsatus grows to only about $43 \mathrm{~mm} \mathrm{CW}$ and within this limit there was no significant difference $(P>0.01)$ between the species.

\section{Foregut clearance rate}

The amount of food remaining in the foreguts of the crabs (expressed as a percentage of the weight of food apparently eaten; $\mathrm{T}=13.5 \pm 1.5^{\circ} \mathrm{C}$ ) after a single, satiated feed was related to time by the regression equations:
Liocarcinus puber: $\mathrm{y}=108.31 \mathrm{e}^{-0.1473} \mathrm{x}$

$\mathrm{r}=0.99, \mathrm{n}=39, \mathrm{P}<0.001$;

L. holsatus: $\mathrm{y}=80.60 \mathrm{e}^{-0.0968} \mathrm{x}$;

$\mathrm{r}=0.99, \mathrm{n}=39, \mathrm{P}<0.001$;

where $y=$ food remaining in the foregut, $\% ; x=$ time, h.

According to these equations the foreguts of both species would be half-full about $5 \mathrm{~h}$ after feeding and be almost empty another $20 \mathrm{~h}$ later. In most cases soft tissue was absent in the foregut $24 \mathrm{~h}$ after feeding while shell fragments were sometimes still found after 36 h. L. puber fed on the algae Laminaria took up to $72 \mathrm{~h}$ to completely clear their foreguts. Faeces started appearing in the containers about $15 \mathrm{~h}$ after feeding and most shell fragments appeared in the faeces about $5 \mathrm{~h}$ later, after which time there was a decrease in the fragments until about $60 \mathrm{~h}$ later when no more fragments appeared. Crabs continued to defaecate in very low amounts for about another $5 \mathrm{~d}$ after which the experiment was terminated.

\section{Diet analysis}

A Spearman rank correlation coefficient of 0.93 (for Liocarcinus puber) and 0.99 (for L. holsatus) showed that the percentage frequency of occurrence of each categorized food item was strongly related to the percentage volume of that item in the foregut. The only notable exceptions were that unidentifiable (mainly organic) material and sand were found in over $88 \%$ of the foreguts examined but contributed to less than $34 \%$ of the total volume; smaller crabs having a higher proportion than the larger ones (Table 1). Similarly, molluscs were found in $67 \%$ of the foreguts examined but contributed to only about $11 \%$ of the total volume of diet.

It was not always possible to identify all of the items in the foreguts of the crabs because of their fragmented and partially digested nature and so broad taxonomic groups were categorized as shown in Table 1. It is probable that soft-bodied animals such as coelenterates were not detected.

Diet of juvenile Liocarcinus puber

Crustaceans were the most important food items of juvenile Liocarcinus puber; they were found in over $72 \%$ of the foreguts examined and constitued $45.6 \%$ of the total volume of the foregut contents (Table 1). Crabs and barnacles occurred nearly 5 times as frequently as other crustaceans and accounted for almost 10 times as much of the volume. The anomurans Por- 
Table 1. Liocarcinus puber and L. holsatus. Foregut contents; Gower Peninsula, South Wales; Jan 1984 to Jul 1985. n: no. of foreguts examined; A: percentage volume of total foregut contents; B: percentage frequency of occurrence

\begin{tabular}{|c|c|c|c|c|c|c|}
\hline \multirow[t]{3}{*}{ Foregut contents } & \multicolumn{4}{|c|}{ L. puber } & \multirow{2}{*}{\multicolumn{2}{|c|}{$\begin{array}{c}\text { L. holsatus } \\
\text { All sizes } \\
(\mathrm{n}=458)\end{array}$}} \\
\hline & \multicolumn{2}{|c|}{$\begin{array}{c}\text { Juvenile } \\
(n=566)\end{array}$} & \multicolumn{2}{|c|}{$\begin{array}{c}\text { Adult } \\
(\mathrm{n}=530)\end{array}$} & & \\
\hline & A & $\mathrm{B}$ & A & $B$ & A & B \\
\hline \multicolumn{7}{|l|}{ Crustacea } \\
\hline Crabs & 32.4 & 72 & 19.4 & 66 & 7.5 & 15 \\
\hline Barnacles & 8.6 & 30 & 3.0 & 29 & - & - \\
\hline Shrimps & - & - & - & - & 22.9 & 34 \\
\hline Others & 4.6 & 22 & 2.9 & 15 & 10.1 & 18 \\
\hline Total & 45.6 & & 25.3 & & 40.5 & \\
\hline \multicolumn{7}{|l|}{ Algae } \\
\hline Brown & 19.6 & 54 & 40.1 & 78 & 1.2 & 7 \\
\hline Others & 1.2 & 7 & 5.5 & 12 & 0.6 & 3 \\
\hline Total & 20.8 & & 45.6 & & 1.8 & \\
\hline \multicolumn{7}{|l|}{ Mollusca } \\
\hline Bivalves & 8.8 & 67 & 7.7 & 44 & 10.8 & 24 \\
\hline Gastropods & 1.3 & 5 & 0.7 & 4 & 0.5 & 2 \\
\hline Total & 10.1 & & 8.4 & & 11.3 & \\
\hline Pisces & 0.4 & 4 & - & - & 10.2 & 24 \\
\hline Polychaeta & 0.1 & 2 & 0.1 & 3 & 2.7 & 13 \\
\hline Unident. material and sand & 22.1 & 88 & 21.5 & 77 & 33.8 & 68 \\
\hline
\end{tabular}

Table 2. Liocarcinus puber. Foregut contents of juvenile crabs (< $40 \mathrm{~mm}$ carapace width) from different localities on the Gower Peninsula, South Wales; Jan 1984 to Jul 1.985. n: no. of foreguts examined; $A$ : percentage volume of total foregut contents; B: percentage frequency of occurrence

\begin{tabular}{|c|c|c|c|c|}
\hline \multirow[t]{2}{*}{ Foregut contents } & \multicolumn{2}{|c|}{$\begin{array}{l}\text { Langland Bay } \\
\qquad(\mathrm{n}=334)\end{array}$} & \multicolumn{2}{|c|}{$\begin{array}{c}\text { Worm's Head, } \\
\text { Rhossili } \\
(n=232)\end{array}$} \\
\hline & A & B & A & B \\
\hline \multicolumn{5}{|l|}{ Crustacea } \\
\hline Crabs & 40.7 & 69 & 24.0 & 64 \\
\hline Barnacles & 6.3 & 12 & 10.8 & 30 \\
\hline Others & 6.0 & 18 & 3.2 & 15 \\
\hline Total & 53.0 & & 38.0 & \\
\hline \multicolumn{5}{|l|}{ Algae } \\
\hline Brown & 25.8 & 53 & 13.4 & 36 \\
\hline Others & 0.2 & 10 & 2.1 & 7 \\
\hline Total & 26.0 & & 15.5 & \\
\hline \multicolumn{5}{|l|}{ Mollusca } \\
\hline Mytilus edulis & 2.5 & 13 & 15.1 & 60 \\
\hline Other bivalves & 0.2 & 2 & 2.3 & 5 \\
\hline Gastropods & 0.2 & 5 & 3.2 & 2 \\
\hline Total & 2.9 & & 20.6 & \\
\hline Pisces & 0.1 & 1 & 0.6 & 2 \\
\hline $\begin{array}{l}\text { Unident. material } \\
\text { and sand }\end{array}$ & 18.0 & 85 & 26.1 & 88 \\
\hline
\end{tabular}

cellana platycheles (over $70 \%$ ) and to a lesser extent Pisidia longicornis (L.) and the brachyurans Pilumnus hirtellus (L.) and Xantho sp. were the predominant species of the former group. The barnacles could not be identified but were likely to be a combination of Elminius modestus Darwin, Semibalanus balanoides (L.), Balanus crenatus Bruguière, B. perforatus Bruguière and Verruca stroemia $O$. Müller. These species are known to occur on the rocky lower intertidal and subtidal zones (Moyse \& Nelson-Smith 1963, Bassindale 1964, Moyse \& Knight-Jones 1965) where L. puber is also found. Molluscs (especially Mytilus edulis) were the second most important food group of crabs from Rhossili while algae (mainly Laminaria and Fucus spp.) were third (Table 2). The dominance of these 2 food groups was reversed for crabs from Langland Bay where molluscs accounted for less than $3 \%$ of the total volume. Laminaria and Fucus were found in similar quantities and mainly in crabs larger than $25 \mathrm{~mm} \mathrm{CW}$; fragments of other algae occurred only occasionally. Items found infrequently and in very small quantities included fish, polychaete worms and brittlestars.

The frequency of crabs with empty foreguts changed throughout the year with more crabs having empty foreguts during winter and less during summer (Fig. 1A). A similar pattern was observed for both the areas. At Langland Bay, crustaceans (mainly crabs and 

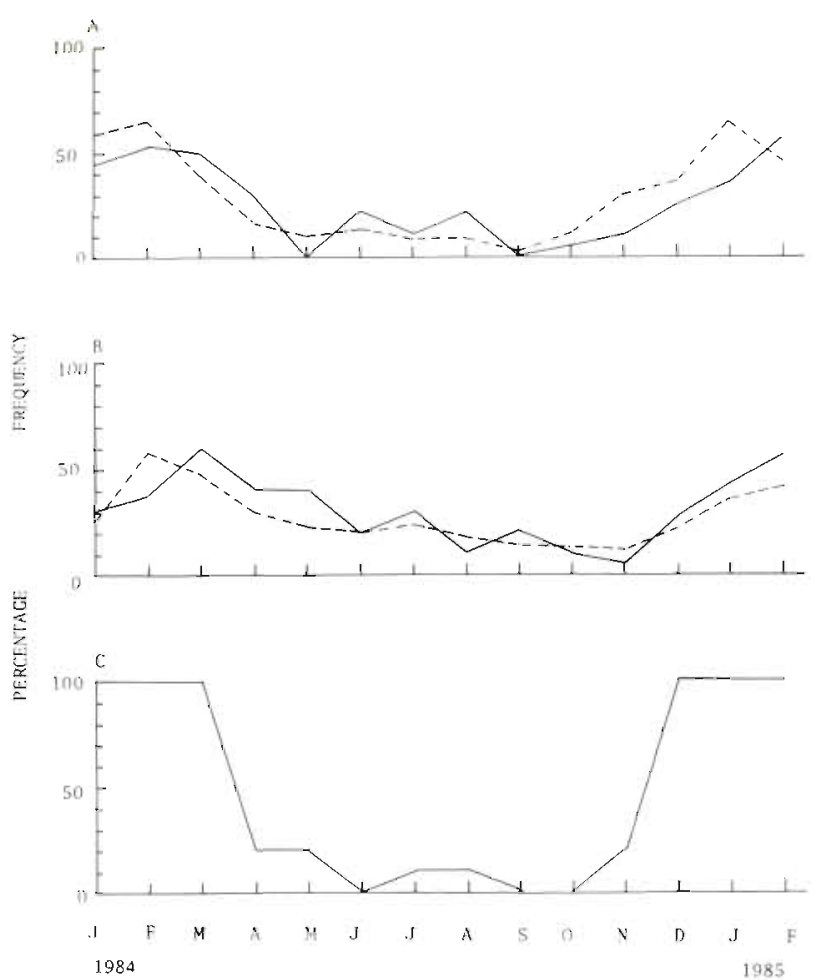

Fig. 1. Liocarcinus puber. Monthly variations in the percentage of hard-shelled crabs with empty foreguts. A: juveniles; B: adult males; C: adult females; ( $\longrightarrow$ Langland Bay; (--) Worm's Head, Rhossili

isopods) and algae represented the most important food items throughout the year (Fig. 2). However, in winter fewer algae and more crustaceans were found in their foreguts. Bivalves (mainly Mytilus edulis) occurred only in autumn while barnacles, fish and polychaetes occurred in low percentages during some months only. In general, a similar pattern was observed for crabs from Rhossili although algae were found in higher percentages during late summer and early autumn while bivalves occurred throughout the year and especially during the warmer seasons. Barnacles were more abundant in the foreguts during spring and early summer.

\section{Diet of adult Liocarcinus puber}

Algae were the most important food items of the adult crabs; they were found in over $80 \%$ of the foreguts examined and constituted $45.6 \%$ of the total volume of the diet (Table 1). Brown algae (mainly Laminaria and to a lesser extent, Fucus) occurred more than 6 times as frequently as others and accounted for almost 8 times as much of the volume. Algae were mainly found in the foreguts of crabs in the early intermoult period. This was particularly evident in the

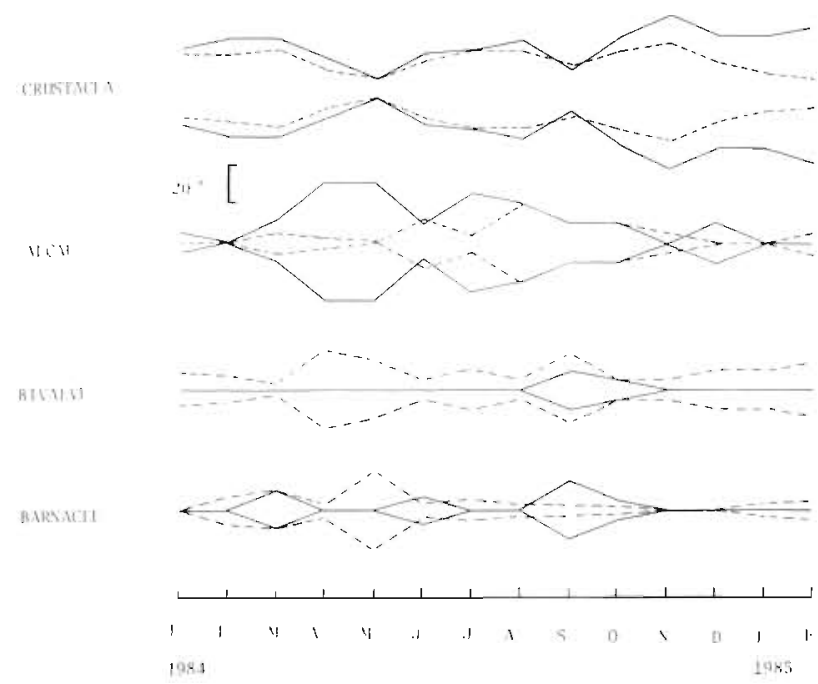

Fig. 2. Liocarcinus puber. Monthly variations in the percentage of the total volume of foregut contents of the 4 major food groups in the foreguts of juvenile crabs. (-) Langland Bay; $(--)$ Worm's Head, Rhossili

adult crabs; the moult stage of juveniles was difficult to determine. Many foreguts examined were completely full of only algae; pieces as large as $5 \times 5 \mathrm{~mm}$ were found in large ( $>65 \mathrm{~mm} \mathrm{CW})$ crabs although $3 \times 3 \mathrm{~mm}$ sizes were more common. Other species of algae were found in very small quantities occasionally. The next most predominant food type was the crustaceans, occurring in over $70 \%$ of the foreguts examined and constituting $25.3 \%$ of the total volume of the foregut contents. As in the case of juvenile crabs, the anomurans Porcellana platycheles (over $60 \%$ ) and to a lesser extent Pisidia longicornis as well as the brachyurans Pilumnus hirtellus, Xantho sp., and juvenile Cancer pagurus L., Carcinus maenas and Liocarcinus puber (in decreasing order of importance) were found in the foreguts of adult L. puber. Barnacles (unidentified but most likely to be the same species as those mentioned for juvenile crabs) and other crustaceans (mainly isopods and natantian decapods) occurred in about $30 \%$ of the foreguts and accounted for about $6 \%$ of the total volume of the contents. Molluscs (mainly Mytilus edulis) were the third major food item, occurring in over $40 \%$ of the foreguts examined but constituting just over $8 \%$ of the volume of the foregut contents. Crabs from Rhossili had a higher percentage of algae and less of crustaceans. Furthermore, females consumed more algae and less molluscs than males (Table 3). Littoral and sublittoral crabs had similar diets.

As in the case of the juveniles, more adult crabs had empty stomachs during winter (especially adult females, most of which were gravid, and those caught from the littoral zone) (Fig. 1). Of the soft-shelled 
Table 3. Liocarcinus puber. Foregut contents of adult crabs (>40 $\mathrm{mm}$ carapace width) from different localities on the Gower Peninsula, South Wales; Jan 1984 to Jul 1985. n: no. of foreguts examined; A: percentage volume of total foregut contents;

B: percentage frequency of occurrence

\begin{tabular}{|c|c|c|c|c|c|c|}
\hline \multirow[t]{3}{*}{ Foregut contents } & \multicolumn{4}{|c|}{ Langland Bay } & \multirow{2}{*}{\multicolumn{2}{|c|}{$\begin{array}{c}\text { Worm's Head, Rhossili } \\
\text { Male } \\
(\mathrm{n}=90)\end{array}$}} \\
\hline & \multicolumn{2}{|c|}{$\begin{array}{c}\text { Male } \\
(n=250)\end{array}$} & \multicolumn{2}{|c|}{$\begin{array}{c}\text { Female } \\
(\mathrm{n}=190)\end{array}$} & & \\
\hline & A & B & A & $\mathrm{B}$ & A & B \\
\hline \multicolumn{7}{|l|}{ Crustacea } \\
\hline Crabs & 20.3 & 40 & 23.0 & 60 & 14.8 & 66 \\
\hline Barnacles & 3.9 & 8 & 1.5 & 15 & 3.5 & 24 \\
\hline Others & 4.0 & 9 & 0.3 & 5 & 2.0 & 5 \\
\hline Total & 28.2 & & 24.8 & & 20.3 & \\
\hline \multicolumn{7}{|l|}{ Algae } \\
\hline Brown & 35.6 & 59 & 44.3 & 90 & 40.5 & 64 \\
\hline Others & 2.5 & 15 & 12.3 & 5 & 1.6 & 8 \\
\hline Total & 38.1 & & 56.6 & & 42.1 & \\
\hline \multicolumn{7}{|l|}{ Mollusca } \\
\hline M. edulis & 8.8 & 13 & 1.8 & 8 & 7.3 & 44 \\
\hline Other bivalves & 0.6 & 1 & 1.6 & 1 & 2.5 & 4 \\
\hline Gastropods & 1.0 & 3 & 0.1 & 1 & 0.6 & 3 \\
\hline Total & 10.4 & & 3.5 & & 10.4 & \\
\hline Pisces & - & - & - & - & - & - \\
\hline Unident. material and sand & 23.4 & 60 & 14.9 & 59 & 26.3 & 77 \\
\hline
\end{tabular}

(recently moulted) crabs, $82 \%$ had empty foreguts; the others had mainly calcareous material and sand in them. The highest percentage of soft-shelled crabs occurred between March and November. At both localities and for both sexes, algae (mainly Laminaria) represented the most important food item between late spring and early autumn (Fig. 3 \& 4). Crustacea (mainly crabs) became the most important diet for males during the other seasons. An increased intake of 1 of these 2 items coincided with the decrease in the

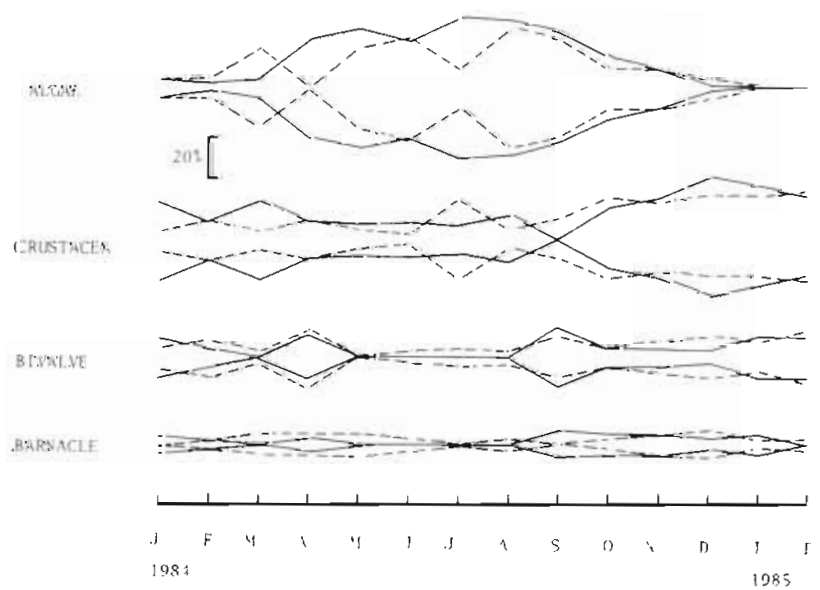

Fig. 3. Liocarcinus puber. Monthly variations in the percentage of the total volume of foregut contents of the 4 major food groups in the foreguts of adult male crabs. (_-) Langland Bay; (---) Worm's Head, Rhossili

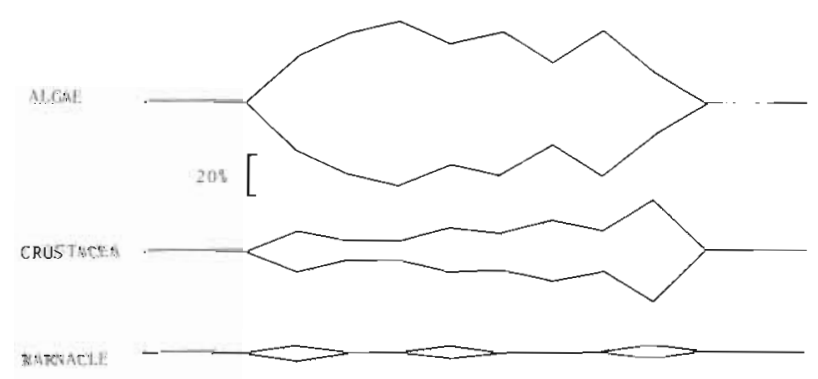

BIVAL.v:

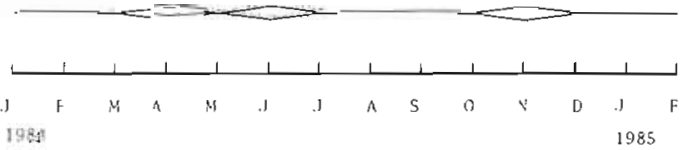

Fig. 4. Liocarcinus puber. Monthly variations in the percentage of the total volume of foregut contents of the 4 major food groups in the foreguts of adult female crabs; Langland Bay

other. In males, bivalves occurred in higher percentages from late summer to late spring. Barnacles and other items such as polychaetes and fish occurred in low percentages during some months only.

\section{Diet of Liocarcinus holsatus}

Since it was very difficult to quantify with certainty the food items of juvenile Liocarcinus holsatus, most analyses were carried out on adult crabs. However, 
Table 4. Liocarcinus holsatus. Foregut contents; Gower Peninsula, South Wales; Jan 1984 to Jul 1985. n: no. of foreguts examined; $A$ : percentage volume of total foregut contents; B: percentage frequency of occurrence

\begin{tabular}{|c|c|c|c|c|}
\hline \multirow[t]{2}{*}{$\begin{array}{l}\text { Foregut } \\
\text { contents }\end{array}$} & \multicolumn{2}{|c|}{$\begin{array}{c}\text { Male } \\
(\mathrm{n}=229)\end{array}$} & \multicolumn{2}{|c|}{$\begin{array}{l}\text { Female } \\
(\mathrm{n}=229)\end{array}$} \\
\hline & A & B & $\mathrm{A}$ & B \\
\hline \multicolumn{5}{|l|}{ Crustacea } \\
\hline Natantia & 21.8 & 26 & 23.9 & 34 \\
\hline Brachyura & 8.6 & 13 & 6.4 & 12 \\
\hline Others & 11.5 & 14 & 8.7 & 17 \\
\hline Total & 41.9 & & 39.0 & \\
\hline \multicolumn{5}{|l|}{ Mollusca } \\
\hline Bivalvia & 8.8 & 16 & 12.8 & 26 \\
\hline Others & 1.0 & 2 & 0 & 0 \\
\hline Total & 9.8 & & 12.8 & \\
\hline Polychaeta & 0.9 & 6 & 4.4 & 10 \\
\hline Pisces & 11.4 & 23 & 9.0 & 17 \\
\hline AJgae & 1.5 & 5 & 2.1 & 6 \\
\hline $\begin{array}{l}\text { Unident. material } \\
\text { and sand }\end{array}$ & 34.7 & 52 & 32.9 & 55 \\
\hline
\end{tabular}

limited analysis of the frequency of occurrence of food items did not show any significant difference in the diet of the juveniles and adults or between crabs from the different localities (Swansea Bay, Oxwich Bay and Carmarthen Bay). Thus, the data were combined and are presented in Table 1. Crustaceans were the most important food of $L$. holsatus; they were found in over $60 \%$ of the foreguts examined and constituted $40.5 \%$ of the total volume of the diet. Natantian decapods (mainly juvenile Crangon spp.) accounted for over $80 \%$ of this. Crabs and lesser crustaceans (isopods, copepods, mysids and euphausids) accounted for the rest. Molluscs (mainly Spisula elliptica [Brown] and occasionally Donax sp., Tellina sp. and Venus sp.) and fish (probably gobies and juvenile pleuronectids) were the next most important categories, being found in over 25 and $22 \%$ of the foreguts and constituting over 11 and $10 \%$ of the total volume of the diet, respectively. Polychaetes accounted for $12 \%$ of the frequency of occurrence but contributed to only $2.7 \%$ of

Table 5. Liocarcinus holsatus. Percentage of crabs with empty foreguts (mean for all months \pm SD); Gower Peninsula, South Wales; Jan 1984 to Jul 1985

\begin{tabular}{|c|c|c|}
\hline Category & Male & Female \\
\hline Crabs infected by Sacculina & $71.8 \pm 16.2$ & $67.3 \pm 14.8$ \\
\hline Non-infected crabs & $32.3 \pm 12.2$ & $39.8 \pm 18.1$ \\
\hline Gravid females & $-\quad-$ & $48.0 \pm 15.3$ \\
\hline
\end{tabular}

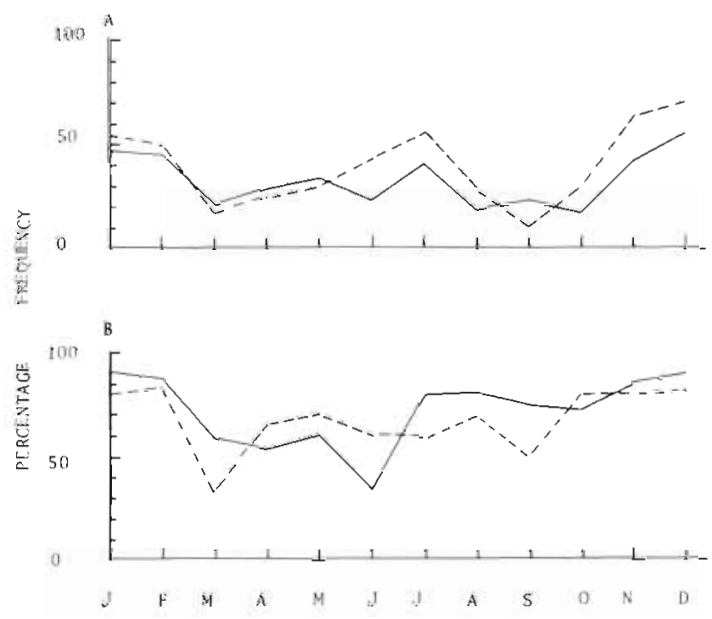

Fig. 5. Liocarcinus holsatus. Monthly variations in the percentage of crabs with empty foreguts. A: healthy crabs; B: crabs parasitised by Sacculina carcini. (-) Langland Bay; (-- ) Worm's Head, Rhossili

the total volume of the diet. Strands of filamentous green and red algae, pieces of Flustra foliacea (L.) and hydroids were found in the foreguts only occasionally. No significant difference in the foregut contents was found between the sexes $(P>0.05)$ (Table 4$)$ or between Sacculina carcini-infected and non-infected crabs $(\mathrm{P}>0.05)$.

The mean of monthly variations in the proportion of empty foreguts was highest for soft-shelled crabs, followed by Sacculina carcini-infected and gravid crabs and lowest for non-infected ones (Table 5). Monthly variations (Fig. 5) showed that there was a peak in the proportion of empty foreguts of non-infected crabs during winter and another during mid-summer. The proportion of empty foreguts in sacculinid crabs fluctuated in an irregular manner throughout the year.

Crustaceans and molluscs were eaten by Liocarcinus

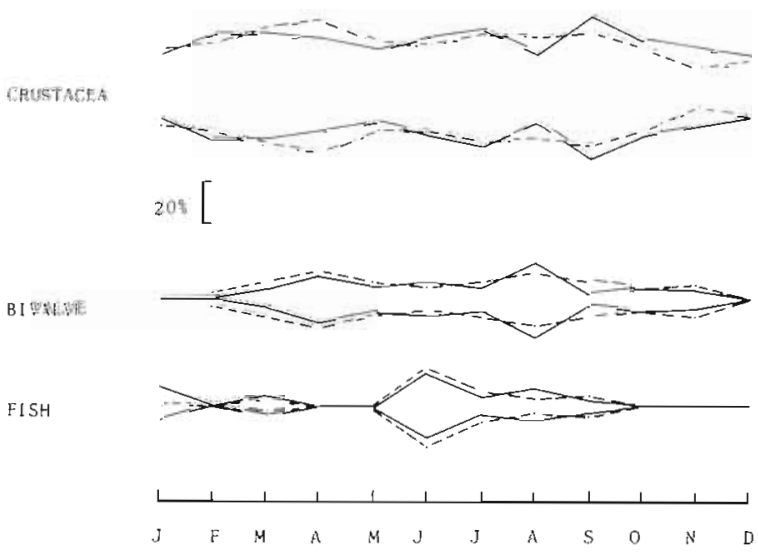

Fig. 6. Liocarcinus holsatus. Monthly variations in the percentage of the total volume of foregut contents of the 3 major food groups in the foreguts of male and female crabs. ( $\longrightarrow$ ) males; $(--)$ females 
holsatus throughout the year, with a higher proportion of the former during summer and autumn and of the latter between late summer and early autumn (Fig. 6). Many juvenile bivalves with shell lengths of about $2 \mathrm{~mm}$ were found in the foreguts between October and November while copepods were particularly plentiful in the foreguts during May and June. Crustacean eggs were frequently found in the foreguts between August and April. Fish occurred in higher percentages during summer and autumn while polychaetes and hydroids occurred in the foreguts mainly between spring and autumn

\section{Predation and prey selection}

In the aquarium, both Liocarcinus puber and L. holsatus accepted a wide variety of food items. However, there was a preference for animal material over plants (algae). A full foregut constituted about $7 \%$ of the body weight and the daily intake of food was between 2 and $5 \%$ of the body weight. When fed after a $72 \mathrm{~h}$ starvation period, a crab could eat up to $7 \%$ of its body weight in less than $3 \mathrm{~h}$ and between 7 and $9 \%$ over 24 h.

When presented with mussels, Liocarcinus puber exhibited a variety of handling methods that have been described by ap Rheinallt \& Hughes (1985). When mussels were presented in a bunch, the small ones were crushed using the mouthparts or chelae and eaten outright while they remained attached to the bunch. Those too large to smash were separated from. the bunch by severing the byssus. The crab then proceeded to open them either by edge chipping, umbo or hinge attack or just prying the valves apart. Of these the first 2 were the more common methods employed. If a large shell was not opened after several attempts, it was left and the crab searched for another. When mussels were present in bunches the crab was able to eat very small ones using its mouthparts (it would normally not be able to handle these mussels if they were individually separated). If other fauna (polychaetes, small crabs, etc.) were present amongst the byssus of the bunch of mussels, the crab usually attacked and ate these first; some even eating the byssus before proceeding to crack the mussel.

The anomuran crab Porcellana platycheles was readily preyed on by Liocarcinus puber. When stones were provided as shelters for the prey the number caught and eaten by $L$. puber was significantly lower $(\mathrm{P}<0.01)$ than when no shelters were provided. The prey handling methods were similar to those described by ap Rheinallt \& Hughes (1985) for L. puber attacking juvenile Carcinus maenas.

In the laboratory, Liocarcinus puber greater than $25 \mathrm{~mm} \mathrm{CW}$ ate Fucus and Laminaria only after a pro- longed starvation period ( $>5$ d). Early intermoult crabs accepted them more readily than crabs in other moult stages. There was no apparent preference between Fucus and Laminaria. However, algal thalli with epiphytes were preferred to those without epiphytes $(P<0.01)$. When feeding on these algae $L$. puber first holds the thallus horizontally with the chelae and scrapes the surface (removing epiphytes) using the maxillipeds. It then holds the thallus vertically and directs an edge into the mouth. Smaller, as well as more starved crabs, grip the edge of the thallus with the mouthparts and pull the thallus outwards with the chelae thereby breaking off bits (which are retained in the mouth) with 'jerky' movements. The larger, as well as less starved crabs, just continue to thrust the edge of the thallus into the mouth while the mouthparts chew and ingest bits. A $70 \mathrm{~mm}$ CW male crab could eat a $50 \times 30 \mathrm{~mm}$ piece of Laminaria in less than $3 \mathrm{~min}$ and then accept more.

When offered with a choice of food items the preference was as follows: crustaceans (shrimps and crabs) $>$ mussels $>$ algae.

\section{DISCUSSION}

\section{Foregut volume and natural diet}

Although carapace width and foregut volume were expected to be related theoretically by a power function (Jewett \& Feder 1982), an exponential function gave a better fit. Hill (1976) also reported the latter for the Indo-Pacific portunid crab Scylla serrata. Analysis of foregut volume revealed that the volume of smallsized $(<22 \mathrm{~mm}$ CW) Liocarcinus puber was slightly greater than that of similar sized L. holsatus; for larger individuals the converse was true. However, the differences were not significant. These foregut volumes are comparable to that of S, serrata (Hill 1976).

Both the volumetric and frequency of occurrence analyses of foregut contents gave similar results except that in some cases the latter method tended to overestimate the importance of unidentifiable material, sand and small animals occurring frequently, but only in small amounts. Errors due to the accumulation of material that are digested or cleared slowly (such as shell, bone, sand and plant material) were introduced by both methods (Hynes 1950, Windell 1968).

The analysis of foregut contents of Liocarcinus puber and $L$. holsatus showed that the latter and juveniles of the former were predators of slow-moving benthic macro-invertebrates, chiefly crustaceans and bivalve molluscs. Fish also formed an important fraction of the diet of L. holsatus. Although it was not possible to identify the fish from the scales, bones and vertebrae 
they may have been benthic species such as gobies (Pomatoschistus spp.) and juvenile pleuronectids; they are known to co-exist with $L$. holsatus and are frequently caught together in trawls. It is unlikely that all, except the smallest, fish are caught alive. Remains of larger fish may be a result of foraging on dead material. Although $L$. holsatus and juvenile $L$. puber had similar classes of organisms as their diet, the species were different; this being a reflection of the differences in the distribution and availability of prey; the reasons also likely to cause the differences in the contribution of different food items of $L$. puber in different areas (Langland Bay and Rhossili). Small bivalves are not common at Langland Bay and this is reflected in the low contribution to the diet of the crabs there. On the other hand, they are plentiful at Rhossili, thus contributing to a higher proportion of the diet of the crabs there. Similar interspecific and intraspecific differences have been reported for other crabs (Ropes 1968, Hill 1976, Paul 1981, Jewett \& Feder 1983, Abbas 1985). The most significant difference between the diets of $L$. holsatus and $L$. puber was that the former fed more on fish, the latter on brown algae.

The chelae of adult Liocarcinus puber are large and powerful and seem well suited to crushing hard-shelled prey. Ebling et al. (1964) found that gastropods crushed by the chelae of $80 \mathrm{~mm} \mathrm{CW} \mathrm{L.} \mathrm{puber} \mathrm{required}$ forces of up to $40 \mathrm{~kg}$ to break the shells. Ap Rheinalit \& Hughes (1985) reported that although the crusher chela of $L$. puber possessed a proximal peg (considered to be an adaptation to feeding on molluscs) it was better equipped for dealing with faster moving, softer bodied prey; this being confirmed by the fact that the crab generally exhibited active and fast-moving behaviour. That algae (Laminaria and Fucus) are the major food component of adult $L$. puber, therefore, comes somewhat as a surprise. González Gurriarán (1978) reported that, based on the percentage of occurrence, algae (Saccorhiza sp. and Laminaria sp.) constituted $8.9 \%$ of the diet (range 2.3 to $16.6 \%$ ) with maximum values (up to $19.5 \%$ ) in crabs that were in the early intermoult stage (Stage B of Drach 1939). In the present study algae accounted for more than twice that proportion and replaced Crustacea as the major food item. This is the highest ever recorded for portunid crabs. Most alga is eaten during the warmer months (April to October) and it is during this time most crabs moult (author's unpubl. data). Hartnoll (1963) reported that alga was the major food component in the diet of several Manx spider crabs such as Inachus dorsettensis (Pennant) (up to $31 \%$ ), I. egyptia (L.) (= Macropodia deflexa Forest) (up to $73 \%$ ) and $I$. phalangium (Fabricius) (up to $76 \%$ ), the variation being determined largely by the distribution and availability of the food item. Grapsid, xanthid, majid, potamid and portunid crabs (particularly juveniles) have also been reported consuming plant material (Ropes 1968, Hill 1976, Warner 1977, Paul 1981, Jewett \& Feder 1982, Williams 1982).

It has not been established whether portunid crabs feed selectively on algae or ingest them incidently along with other items and whether or not they can digest plant material. Many specimens of Liocarcinus puber were found with their foreguts completely full of brown algae only. These algae are known to support numerous epiphytes including hydroids, bryozoans, coelenterates, molluscs, polychaetes and crustaceans (Hayward 1980, Seed et al. 1981), most of which cannot be identified if present in the foreguts of crabs. Laboratory experiments also showed that the crabs had a preference for algae with epiphytes. However, the observed handling methods suggest that the crab can scrape off the epiphytes from the surface of the algae without having to ingest the thallus. Preference for algae with epiphytes may, therefore, be related to greater nutritive value or greater chemoreception. Laverack (1963) reported that crustacean chemosensitivity was greatest for certain amino acids found in marine fish and invertebrates. This may also partially explain why animal material is preferred by these crabs. Examination of the faeces of crabs fed on Fucus and Laminaria showed that much of the material was digested. Sova et al. (1970) and Hylleberg-Kristensen (1972) found very strong carbohydrase (and in particular, laminarinase) activity in the foregut fluids of portunid crabs. Laminarin (a polysaccharide sugar) is a principal storage product of marine Phaeophyta (constituting 10 to $30 \%$ and 1 to $19 \%$ dry weight in Laminariaceae and Fucaceae, respectively) (Chapman \& Chapman 1980). All these results and observations strongly suggest that $L$. puber feeds selectively on brown algae and can digest them.

The difference in the diet composition of juvenile and adult Liocarcinus puber presumably results from the size difference, change in the cheliped strength and foraging behaviour (Elner 1980). Juveniles probably can gain access to a lot more of the smaller crustaceans which live under stones and boulders and amongst the holdfasts of seaweeds. That fewer molluscs are eaten by adult females is likely to be a reflection of cheliped strength. Diet differences in different size groups of other species of crabs have been frequently reported (Ropes 1969, Paul 1981, Jewett \& Feder 1982, Abbas 1985). González Gurriarán (1978) found that the only significant difference between the diets of juvenile and adult $L$. puber was in the consumption of echinoderms; the adults consuming more.

Seasonal variations in the animal diet of Liocarcinus holsatus and $L$. puber as demonstrated in the present study are presumably due to changes in the availabil- 
ity of prey organisms throughout the year. The peak abundance of bivalves in the diet of $L$. holsatus and $L$. puber in autumn may coincide with the attainment of a preferred size by, and a higher density of, the bivalves. These presumably settled in early summer (Warwick \& George 1980). The bivalves (Spisula, Donax and Venus) eaten by $L$. holsatus are burrowers and it is possible that in winter they burrow deeper and are not easily accessible to predators (Walne \& Dean 1972, Arnold 1984, Abbas 1985). Size selection of these bivalves may be a result of relative shell to chelae strength (Elner 1978) and the burrowing behaviour of the bivalves; smaller individuals occur near the surface of the sand (Abbas 1985). The high occurrence of copepods in the foreguts of $L$. holsatus during late spring and early summer coincides with their high abundance (Isaac 1980).

The high abundance of brown algae in the foregut of Liocarcinus puber from spring to autumn cannot be attributed to availability alone. González Gurriarán (1978) reported that the highest percentage of occurrence of algae occurred in the foreguts of recently moulted crabs (moult Stage B of Drach 1939). The present study showed similar results. The highest moulting frequency of $L$. puber is between April and October and as expected, it coincides with the high abundance of algae in the foreguts of the crabs. However, this may not be the only explanation. The abundance of the different food reserves in Laminaria and Fucus vary with species, area and season (Chapman \& Chapman 1980). Black (1950) found that mannitol is lowest in fronds in spring while crude protein, ash and alginic acid were at a maximum. These marine algae are also known to translocate and accumulate photosynthates in the lowermost $20 \mathrm{~cm}$ of the frond (Lüning et al. 1973) when not growing new fronds. However, when actively growing (from spring to autumn in the case of Fucus, L. digitata and L. saccharina) the stored reserves are translocated to the growing tips or fronds (Chapman \& Craigre 1977). It is also during spring and summer that epiphytes are abundant on the thallus of these algae (Seed et al. 1981), some showing preferential settiement on the younger parts of the fronds (Stebbing 1971). Therefore, it is likely that the nutritive value and palatability of these algae are greatest from spring to autumn and this may be another reason as to why they are eaten mainly during this period. The early intermoult (B) stage of crustaceans is the period prior to main tissue growth (Drach 1939) and it is possible that during this stage $L$. puber eats whatever is available and algae, being abundant in the area and sessile, are then eaten. Algae also form a supplementary or substitute component of the diet when there is a lack of other food (González Gurriarán 1978).

Some soft, newly moulted Liocarcinus puber and $L$. holsatus had large quantities of calcareous material in their foreguts and it is likely that they use this for forming new exoskeleton (Knudsen 1959. Williams 1982).

\section{Feeding rates and activity patterns}

Foregut clearance rate estimated during starvation after a single meal may be slower than expected because it does not take into account the possibility of subsequent meals 'pushing food along. The exponential clearance function therefore may be a special case. However, results suggest that foregut clearance of Liocarcinus puber and L. holsatus is generally quite rapid (although items such as shells and algae take longer). This is in agreement with Abbas (1985) who found that a full stomach of Carcinus maenas becomes empty after 24 to $36 \mathrm{~h}$ of starvation. Hill (1976) reported that clearance of similar food items from the stomach of Scylla serrata took only about $12 \mathrm{~h}$. This rapid clearance may have been a result of the higher temperatures at which the experiments were carried out and of the adaptation of the crab itself which is a tropical species and metabolically more active. L. puber collected from the intertidal zone during the afternoon, just after the retreat of the tide, and those collected subtidally had partially full foreguts. The foregut fullness of $L$. puber collected at different times of the day and in relation to the tidal cycle showed that crabs collected at low tides in the morning had a higher mean foregut fullness than those collected at low tides during the afternoon or evening. This suggests that $L$. puber feeds mainly during the night but also (to a lesser extent) during the day when submerged. Diving observations, feeding experiments and activity records all indicate mainly nocturnal feeding thus confirming the observations of Kitching et al. (1959) and Ebling et al. (1964). L. holsatus tends to feed during incoming or outgoing tides with the highest percentage of full foreguts at low and high tides. It is likely that during these periods potential prey such as crustaceans and juvenile fish migrate with the tides (Rodriguez 1970, Gibson 1978), while many bivalves extend their siphons to feed on allochthonous or resuspended material (Brafield 1978) and are most susceptible to predation by the crabs. No diurnal difference was apparent. L. holsatus is predominantly subtidal and the water (usually turbid) provides appropriate cover at all times. Crabs with empty stomachs were most abundant in winter. A higher proportion of empty foreguts was found in parasitised and gravid crabs. All adult female L. puber sampled between December and March had empty foreguts; most of these crabs were gravid. These crabs are less active and feed less (González Gurriarán 1977) particularly if temperatures are low. 
It appears that both species can eat about $4 \%$ of their own body weight every $24 \mathrm{~h}$ when a constant supply of food is available, and about twice that if starved. Similar rates have been reported for the spider crab Libinia emarginata Leach (Aldrich 1976).

\section{Predation and prey selection}

The methods used by Liocarcinus puber to open bivalves and handle crustacean prey were similar to those described for other portunid crabs by Elner (1978), Williams (1978), Hughes \& Seed (1981), Abbas (1985) and ap Rheinallt \& Hughes (1985). In most cases the major chela is used to break open or tear the prey because it is generally much stronger (Brown et al. 1979, Warner et al. 1982). Variations in the morphology and strength of chelae of natural population of crabs feeding on distinctly different foods may exist (AbbyKalio \& Warner 1984).

The increase in attack success rate with increasing crustacean prey size has been attributed to the efficiency of prey enclosure by the periopods and the firmness of chelal grip of Liocarcinus puber (ap Rheinallt \& Hughes 1985). However, a maximum critical size must exist. L. puber will attack large crabs only if the latter are more vulnerable; as in the case when appendages (mainly the chelae) are missing or when moulting takes place.

As mentioned earlier, the availability of potential food items is not the only factor determining the diet of crabs. Many species show preference not only to the type of prey (Hancock 1974, Aldrich 1976) but also to a certain size group (Elner 1978, Hughes \& Seed 1981, ap Rheinallt \& Hughes 1985). This preference is thought to be related to higher prey value (Elner \& Hughes 1978, Elner \& Raffaeli 1980, Hughes \& Seed 1981, Abbas 1985). Field results and laboratory studies show that Liocarcinus puber and L. holsatus also avoid eating certain organisms. The starfish Asterias rubens (L.), sponges and sea anemones are common in the areas where L. puber inhabits. None of these organisms have been found in the foreguts of $L$. puber; the first 2 would have been easy to detect if present. Similarly, brittlestars, sponges, hydroids and algae are caught in large numbers with $L$. holsatus but neither of the first 2 and very few of the last have been found in their foreguts. In the laboratory none of these items were eaten even when the crabs were starved for several weeks. It is likely that most of these organisms possess defensive mechanisms such as spines, spicules and toxic chemicals to protect them from crab predation (Nicol 1960).

Muntz et al. (1965) found that the predatory activity of crabs was an important factor in determining the distribution of prey species. Conversely, the availabil- ity of food items may be a factor limiting the distribution of crabs (Hartnoll 1963).

Finally, the results of this and other studies cited above strongly suggest that despite the diversity in their food and feeding habits, portunid crabs are opportunistic omnivores with a preference for animal food and the behaviour of active predators of sessile and slow-moving macro-invertebrates

Acknowledgements. I am grateful to Prof. J. S. Ryland for the provision of laboratory facilities and to Dr. J. Moyse for his advice and critical reading of the manuscript. I also express my appreciation to Mr. G. Howells and the captain and crew of R.V. Venturous for obtaining trawl samples. My dear wife, Saroj, did all the typing. Financial support by the Association of Commonwealth Universities, U.K., and the University of the South Pacific, Fiji Islands, is gratefully acknowledged.

\section{LITERATURE CITED}

Abbas, S. A. M. (1985). Predation of infaunal bivalves by Carcinus maenas (L.) in the Burry Inlet, S. Wales. Ph. D. thesis, Univ. of Wales, Swansea

Abby-Kalio, N. J., Warner, G. F. (1984). Effects of two different feeding regimes on the chela closer muscles of the shore crab Carcinus maenas (L.). Mar. Behav. Physiol. 11: 209-218

Aldrich, J. C. (1976). The spider crab Libinia emarginata Leach 1815 (Decapoda: Brachyura) and the starfish, an unsuitable predator and a co-operative prey. Crustaceana 31: $151-156$

ap Rheinallt, T., Hughes, R. N. (1985). Handling methods used by the velvet swimming crab Liocarcinus puber when feeding on molluscs and shore crabs. Mar. Ecol. Prog. Ser. 25: 63-70

Arnold, W. S. (1984). The effects of prey size, and sediment composition on the rate of predation of the blue crab, Callinectes sapidus Rathbun, on the hard clam Mercenaria mercenaria (L.). J. exp. mar. Biol. Ecol. 83 (3): $207-220$

Bassindale, R. (1964). British barnacles with keys and notes for the identification of the species. Synopses of the British Fauna No. 14, Linn. Soc., Lond.

Black, W. A. P. (1950). Seasonal variation in weight and chemical composition of the common British Laminariceae. J. mar. biol. Ass. U.K. 29: 45-72

Brafield, A. E. (1978). Life in sandy shores. Studies in Biology No. 89, Edward Arnold, London

Brown, S. C., Cassuto, S. R., Loos, R. W. (1979). Biomechanics of chelipeds in some decapod crustaceans. J. Zool., Lond. 188: $143-159$

Caine, E. A. (1974). Feeding of Ovalipes guadulpensis and morphological adaptations to a burrowing existence. Biol. Bull. mar. biol. Lab., Woods Hole 147: 550-559

Chapman, A. R. O., Craigre, J. S. (1977). Seasonal growth in Laminaria longicruris: Relation with dissolved inorganic nutrients and internal reserves of nitrogen. Mar. Biol. 4: 197-205

Chapman, V. J., Chapman, D. J. (1980). Seaweeds and their uses. Chapman and Hall, London

Christiansen, M. E. (1969). Marine invertebrates of Scandinavia No. 2. Crustacea, Decapoda, Brachyura. Universitetsforlaget, Oslo

Crothers, J. H. (1968). The biology of the shore crab Carcinus 
maenas (L.). 2. The life of the adult crab. Fld Stud. 2 579-614

Drach, P. (1939). Mue et cycle d'intermue chez les crustacés décapodes. Ann. inst. océanogr Monaco 19: 103-391

Du Preez, H. H. (1984). Molluscan predation by Ovalipes punctatus (De Haan) (Crustacea: Brachyura: Portunidae). J. exp. mar. Biol. Ecol. 84: 55-71

Ebling, F. J., Kitching, J. A., Muntz, L., Taylor, C. M. (1964) The ecology of Lough Ine. XIII. Experimental observations of the destruction of Mytilus edulis and Nucella lapillus by crabs. J. Anim. Ecol. 33: 73-82

Elner, R. W. (1978). The mechanics of predation by the shore crab. Carcinus maenas (L.) on the edible mussel, Mytilus edulis (L.). Oecologia (Berl.) 36: 333-344

Elner, R. W. (1980). The influence of temperature, sex and chela size in the foraging strategy of the shore crab, Carcinus maenas (L.). Mar. Behav. Physiol. 7: 15-24

Elner, R. W., Hughes, R. N. (1978). Energy maximization in the diet of the shore crab, Carcinus maenas. J. Anim. Ecol. 47: 103-116

Elner, R. W., Raffaeli, D. G. (1980). Interactions between two marine snails, Littorina rudis Maton and L. nigrolineata Gray, a predator, Carcinus maenas (L.), and a parasite, Microphallus similis Jagarskiold. J. exp. mar. Biol. Ecol 43: $151-160$

Gibson, R. N. (1978). Lunar and tidal rhythms in fish. In Thorpe, J. E. (ed.) Rhythmic activity in fishes. Academic Press, London, p. 201-213

González Gurriarán, E. (1977). Alguno aspectos del comportamiento en la nécora Macropipus puber (L.) (Decapoda Brachyura). Boln. R. Soc. Espan. Hist. Nat. (Biol.). 75 $473-479$

González Gurriarán, E. (1978). Introducción al estudio de la alimentación en la nécora, Macropipus puber (L.) (Decapoda, Brachyura). Boln Inst. esp. Oceanogr. 4 (242): 81-93

González Gurriarán, E. (1981). La nécora Macropipus puber (L.) (Decapoda, Portunidae) en los poliginos de bateas de la ría de Arousa: Contribución al estudio de su biologia. Resumen de la tesis presentada para aspivar al grado de Doctor en Biologia, Univ. de Santiago, España

Hancock, D. A. (1974). Attraction and avoidance in marine invertebrates and their possible role in developing an artificial bait. J. Cons. int. Explor. Mer 35: 328-331

Hartnoll, R. G. (1963). The biology of Manx spider crabs. Proc. zool. Soc. 141: 423-496

Hayward, P. J. (1980). Invertebrate epiphytes of coastal marine algae in the shore environment. In: Price, J. H., Irvine, D. E. G., Farnham, W. F. (ed.) Ecosystems. Syst. Assoc. Sp. Vol. No. 17(b). Academic Press, London, p. $761-787$

Hill, B. J. (1976). Natural food, foregut clearance-rate and activity of the crab Scylla serrata. Mar. Biol. 34(1): 109-116

Hughes, R. N., Seed, R. (1981). Size selection of mussels by the blue crab Callinectes sapidus: energy maximizer or time minimizer? Mar. Ecol. Prog. Ser 6: 83-89

Hylleberg-Kristensen, J. (1972). Carbohydrases of some marine invertebrates with notes on their food and on the natural occurrence of the carbohydrates studied. Mar Biol. 14: 130-142

Hynes, H. B. N. (1950). The food of freshwater sticklebacks (Gasterosteus aculeatus and Pygosteus pungitius) with a review of the methods used in the studies of food of fishes. J. Anim. Ecol. 19: 36-58

Ingle, R. W. (1983). Shallow-water crabs. Synopses of the British Fauna: a new series, Vol. 25. Linn. Soc., London
Isaac, M. J. (1980). The zooplankton of Swansea Bay. In: Collins, M. B., Banner, F. T., Tyler, P. A., Wakefield, S. J., James, E. A. (ed.) Industrialised embayments and their environmental problems. A case study of Swansea Bay. Pergamon Press, London, p. 487-505

Jewett, S. C., Feder, H. M. (1982). Food and feeding of the king crab, Paralithodes camtschatia near Kodiak Island, Alaska. Mar. Biol. 66: 243-250

Jewett, S. C., Feder, H. M. (1983). Food of the tanner crab Chionoecetes bairdi near Kodiak Island, Alaska. J. Crust. Biol. 3 (2): 196-207

Kitching, J. A., Sloane, J. F., Ebling, F. J. (1959). The ecology of Lough Inne. VIII. Mussels and their predators. J. Anim. Ecol. 28: 331-341

Knudsen, J. W. (1959). Shell formation and growth of the Californian xanthid crabs. Ecology 40: 113-115

Laverack, M. S. (1963). Aspects of chemoreception in crustacea. Comp. Biochem. Physiol. 8: 141-151

Lüning, K., Schmitz, K., Willenbrink, J. (1973). CO fixation and translocation in benthic marine algae. III. Rates and ecological significance of translocation in Laminaria hyperborea and L. saccharina. Mar. Biol. 23: 275-281

MacMullen, P. H. (1983). The fishery of the velvet swimming crab Macropipus puber. Sea Fish Indust. Auth. Tech. Rep. No. 218, Hull, U. K.

Moyse, J., Nelson-Smith, A. (1963). Zonation of animals and plants on rocky shores around Dale, Pembrokeshire. Fld Stud. 1: 1-31

Moyse, J., Knight-Jones, E. W. (1965). Biology of cirripede larvae. Proc. Symp. on Crustacea, Mar. biol. Ass. India, p. 595-611

Muntz, L., Ebling, F. J., Kitching, J. A. (1965). The ecology of Lough Inne. XIV Predatory activity of large crabs. J. Anim. Ecol. 34: 315-329

Nicol, J. A. C. (1960). The biology of marine animals. Pitman and Sons, London

Paul, R. K. G. (1981). Natural diet, feeding and predatory activity of the crabs Callinectes arcuatus and $C$. toxotes (Decapoda, Brachyura, Portunidae). Mar. Ecol. Prog. Ser. 6: 91-99

Rodriguez, G. (1970). Ecological behaviour of some littoral caridean decapod crustacea. Ph. D. thesis, Univ. of Wales, Swansea

Ropes, J. W. (1968). The feeding habits of the green crab Carcinus maenas (L.). Fish Wildl. Serv. Fish. Bull. 67: $183-203$

Seed, R., Elliot, M. N., Boaden, P. J. S., O'Connor, R. J. (1981). The composition and seasonal changes amongst the epifauna associated with Fucus serratus L. in Strangford Lough, Northern Ireland. Cah. Biol. mar. 22: 243-266

Snedecor, G. W., Cochran, W. G. (1980). Statistical methods, 7 th edn. lowa State Univ., Ames

Sova, V V., Elyakova, L. A., Vaskovsky, V E. (1970). The distribution of laminarinases in marine invertebrates. Comp. Biochem. Physiol. 32: 459-464

Stebbing, A. R. D. (1971). Preferential settlement of a bryozoan and sperpulid larvae on the younger parts of Laminaria fronds. J. mar. biol. Ass. U.K. 52: 765-772

Tagat $z$ M. E. (1968). Biology of the blue swimming crab Callinectes sapidus Rathbun, in the St. John River, Florida. Fish Wildl. Serv. Fish. Bull. 67: 17-33

Walne, P. R., Dean, G. L. (1972). Experiments on predation by the shore crab, Carcinus maenas L. on Mytilus and Mercenaria. J. Cons. int. Explor Mer 34: 190-199

Warner, G. F. (1977). The biology of crabs. Elek Sci., London Wamer, G. F., Chapman, D., Hawkey, N., Waring, D. G. (1982). Structure and function of chelae and chela closer 
muscles of the shore crab Carcinus maenas (Crustacea: Brachyura). J. Zool., Lond. 196: 431-438

Warwick, R. M., George, C. L. (1980). Annual macrofauna production in an Abra community. In: Collins, M. B., Banner, F. T., Tyler, P. A., Wakefield, S. J., James, E. A. (ed.) Industrialised embayments and their environmental problems. A case study of Swansea Bay. Pergamon Press, Oxford, p. 517-538

Williams, M. J. (1978). Opening of bivalve shells by the mud crab Scylla serrata Forskal. Aust. J. mar Freshwat. Res. 29: 699-702

Williams, M. J. (1981). Methods for analysis of natural diet in portunid crabs (Crustacea: Decapoda: Portunidae). J. exp. mar. Biol. Ecol. 52: 103-113

Williams, M. J. (1982). Natural food and feeding in the commercial sand crab Portunus pelagicus Linnaeus, 1766 (Crustacea: Decapoda: Portunidae) in Moreton Bay, Queensland. J. exp. mar. Biol. Ecol. 59: 165-176

Windell, J. $T$ (1968). Food analysis and rate of digestion. In: Ricker, W. E. (ed.) Methods for assessment of fish production in freshwaters. IBP Handbook No. 3, p. 216-226

Zar, J. H. (1974). Biostatistical analysis. Prentice-Hall Inc., New Jersey

This article was submitted to the editor; it was accepted for printing on March 21, 1986 